\title{
Pengembangan Desa Berdaya Bebas Covid-19 melalui Pendekatan Holistic
}

\author{
Sutarmi, Tavip Indrayana, Marlynda Happy Nurmalita Sari \\ Email: sutarmisaja15@gmail.com \\ Poltekkes Kemenkes Semarang, Indonesia \\ Jl. Tirto Agung, Pedalangan, Banyumanik, Kota Semarang, Jawa Tengah \\ Telp/Fax. (024) 7460274
}

\begin{abstract}
Abstrak
Penyebaran Covid-19 belum bisa dihentikan, namun masyarakat harus mulai beradaptasi dengan kebiasaan hidup baru atau "New Normal Life". Kegiatan ini bertujuanmeningkatkan pengetahuandan pemberdayaan masyarakat dalam beradaptasi kehidupan baru masa pandemi Covid-19. Sasaran warga Desa Temurejo, Blora.Metode meliputi persiapan, pengorganisasian, edukasi dan latihan, pemberdayaan diri dan integrasi, implementasi dan terminasi. Kegiatan diawali koordinasi, persiapan, penentuan wilayah dan jadwal kegiatan. Dilanjutkan pengorganisasian, koordinasi dengan kepala Desa Temurejo, perwakilan masyarakat dan gugus Covid -19. Edukasi dan latihan untuk meningkatkan pengetahuan dan pemahaman masyarakat tentang protokol kesehatan dan pemberdayaan diri di masa pandemi. Pemberdayaan dan integrasi dengan menggali potensi masyarakat yang diintegrasikan dengan kebutuhan urgent di era pandemi yaitu pembuatan alat cuci tangan metode hinjak. Implementasi dengan serah terima alat cuci tangan dan bahan desinfektan, demonstrasi cuci tangan dan penyemprotan tempat umum. Tahap akhir monitoring evaluasi dan pelaporan kegiatan.Kegiatanterlaksana sesuai dengan target dan rencana kegiatan. Potensi SDM yang adekuat dalam menerima IPTEK prosedur protokol kesehatan dan pendampingan pembuatan alat cuci tangan dengan metode hinjak dapat dikembangkan menjadi usaha produktif menjadi sebuah UMKM di era new normal life. Diharapkan ada kegiatan serupa yang terjadwal secara rutin untuk menjaga perilaku hidup sehat dan pengembangan kegiatan pembentukan UMKM berbasis potensi masyarakat.
\end{abstract}

Kata Kunci: Covid-19; era new normal; protokol kesehatan.

\begin{abstract}
The spread of Covid-19 cannot be stopped, but people must start adapting to new life habits or "New Normal Life". This activity aims to increase knowledge and empower the community in adapting to a new life during the Covid-19 pandemic. Target residents of Temurejo Village, Blora. Methods include preparation, organizing, education and training, self-empowerment and integration, implementation and termination. The activity begins with coordination, preparation, determining the territory and schedule of activities. Followed by organizing, coordinating with the head of Temurejo Village, community representatives and the Covid -19 cluster. Education and training to increase public knowledge and understanding of health protocols and selfempowerment during a pandemic. Empowerment and integration by exploring the potential of the community which is integrated with the urgent need in the pandemic era, namely the manufacture of handwashing with the stepping method. Implementation by handing over hand-washing tools and disinfectants, demonstrations of washing hands and spraying public places. The final stage is monitoring evaluation and activity reporting. Activities carried out in accordance with the targets and activity plans. The potential of adequate human resources in receiving science and technology, health protocol procedures and assistance in making hand washing equipment using the stepping method can be developed into a productive effort to become a UMKM in the era of new normal life.It is hoped that there will be similar activities that are regularly scheduled to maintain a healthy lifestyle and develop community potential-based UMKM formation activities.
\end{abstract}

Keywords: Covid-19; new normal era; health protocols 


\section{Pendahuluan}

Corona virus (Covid-19) merupakan virus yang menyerang siapa saja melalui saluran pernafasan. Sejak ditemukan pertama kali di Wuhan, China pada 31 Desember 2019 Covid-19 dengan cepat telah menyebar ke beberapa negara, dan merupakan penyakit yang perkembangannya sangat cepat dan mewabah sehingga pada tanggal 11 Maret 2019, kasus ini ditetapkan sebagai kejadian pandemic global oleh World Health Organization. ${ }^{1}$ Covid-19 telah menyebar di 213 negara dengan jumlah kasus terkonfirmasi positif Covid-19 sebanyak 2.549.632 kasus, dengan jumlah kematian sebanyak 175.825 orang. ${ }^{1}$ Sedangkan secara nasional data kasus positif Covid-19 sebanyak 7.775 kasus dengan jumlah meninggal sebanyak 647 orang. $^{2}$

Hasil analisis data tentang coronavirus menunjukkan bahwa covid-19 memiliki angka kematian sekitar 2\%-3\%, jauh lebih rendah dari wabah lain (SARS, MERS, Swine Flu). ${ }^{3}$ Sehingga masyarakat tidak perlu panik tetapi tentunya tetap waspada dengan melakukan pencegahan sesuai dengan anjuran. Diperlukan penanganan pandemi COVID-19 yang cepat, tepat, fokus dan adanya sinergi antara pemerintah dan masyarakat. Hal ini dapat dicapai dengan dilakukannya pemberdayaan masyarakat dalam pencegahan COVID-19. Upaya untuk mengantisipasi penyebaran virus tersebut, maka penggunaan masker disertai dengan peningkatan kebiasaan penggunaan pembersih tangan yang mengandung alkohol atau mencuci tangan dengan menggunakan air dan sabun menjadi salah satu upaya yang direkomendasikan terutama bagi yang sedang merawat pasien terinfeksi Coronavirus dan orang yang mengalami gejala batuk, demam dan gangguan pernapasan. ${ }^{4}$

Hingga saat ini, penyebaran virus belum bisa dihentikan karena belum ditemukan obat atau vaksinnya. Pandemi Covid-19 belum berakhir, namun kehidupan terus berjalan untuk itu masyarakat harus mulai beradaptasi dengan kebiasaan hidup baru atau disebut dengan "New Normal Life", yaitu perubahan perilaku untuk tetap melakukan aktivitas normal dengan ditambah menerapkan protokol kesehatan untuk mencegah terjadinya penularan Covid-19. Melalui Kementerian Kesehatan, pemerintah Indonesia menginstruksikan pelaksanaan upaya pencegahan penyebaran Covid-19 sebagaimana yang direkomendasikan oleh WHO, yaitu kesadaran dan kepatuhan dalam penggunaan masker ketika di luar rumah dan Cuci Tangan Pakai Sabun (CTPS). ${ }^{5}$ Pedoman pencegahan dan pengendalian Covid-19 di Masyarakat berdasarkan KMK HK.01.07/MENKES/413/2020 diantaranya physical distancing, menjaga kebersihan tangan, etika batuk/bersin, pemakaian masker, pembatasan aktivitas luar rumah, mempertimbangkan pembatasan 
sosial berskala besar (PSBB), memastikan akses kebersihan tangan di depan gedung fasilitas umum dan pusat transportasi dengan menyiapkan fasilitas cuci tangan. ${ }^{5,6}$ Tujuan dari pengabdian masyarakat ini meningkatkan pengetahuandan memberdayakan masyarakat dalam beradaptasi kehidupan baru di masa pandemi Covid-19.

\section{Metode}

Metode yang digunakan dalam kegiatan meliputi enam tahapan yaitu fase persiapan, pengorganisasian, edukasi dan latihan, pemberdayaan diri dan integrasi, implemnetasi dan terminasi \& evaluasi.7,8

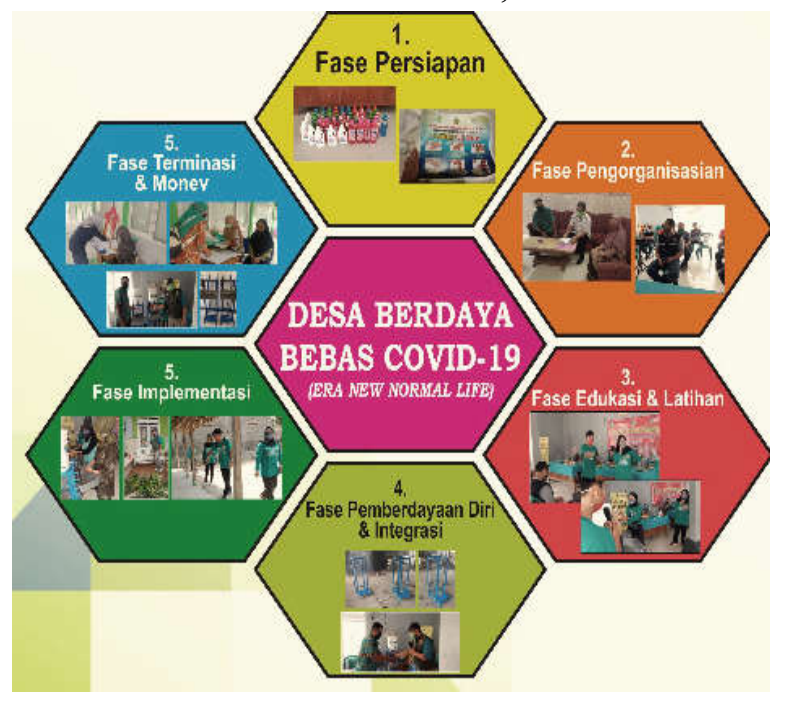

Kegiatan diawali dengan koordinasi, persiapan, penetuan wilayah dan jadwal kegiatan. Dilanjutkan tahap pengorganisasian, koordinasi dengan kepala Desa Temurejo, perawakilan masyarakat dan gugus Covid -19. Pada tahap edukasi dan latihan ditujukan untuk meningkatkan pengetahuan dan pemahaman masyarakat tentang protokol kesehatan di era new normal dan pemberdayaan diri di masa pandemi. Pada kegiatan pemberdayaan dan integrasi, dimulai dengan menggali potensi masyarakat yang diintegrasikan dengan kebutuhan urgent di era pandemi yaitu pembuatan alat cuci tangan dengan metode hinjak. Perguruan tinggi bekerja sama dengan bengkel dan tekhnisi las besi untuk memberikan pendampingan dan produksi. Memasuki tahap kelima yaitu implementasi, dimulai dengan serah terima alat cuci tangan dan bahan desinfectan untuk penyemprotan, demonstrasi cuci tangan dan penyemprotan tempat umum dan ibadah. Pada tahap akhir kegiatan dilakukan monitoring evaluasi dan pelaporan kegiatan

\section{Hasil dan Pembahasan}

Hasil dari kegiatan pengabdian masyarakat digambarkan pada luaran pada tiap - tiap tahapan. Pada tahap persiapan dimulai dengan penentuan lokasi, pemantapan protokol pelaksanaan, perijinan dan koordinasi dengan wilayah binaan. Persiapan team pengabdi dalam pembagian job deskripsi dan persiapan alat dan bahan.

Tahap pengorganisaian kegiatan dimulai dengan kegiatan fokus group diskusi dengan perwakilan pemerintah desa dan perangkat desa, satgas covid- 19, tenaga kesehatan, kader kesehatan, dan tokoh masyarakatdan tokoh agamauntuk menyampaikan tujuan 
adanya kegiatan pengabmas yaitu pengembangan desa berdaya bebas covid-19 dengan pendekatan holistik. Pelaksanaan tahap pengorganisasian dilaksanakan di ruang pertemuan Desa Temurejo pada tanggal 02 Juni 2020 jam $09.00 \mathrm{~s} / \mathrm{d}$ jam $12.00 \mathrm{WIB}$.

Kegiatan pada tahap ke - 3 yaitu edukasi dan latihan. Kegiatan Edukasi dilaksanakan di Aula pertemuan pada tanggal $08 \mathrm{~s} / \mathrm{d} 26$ Juni 2020 mulai jam 08.00 - 15.00 WIB dihadiri oleh semua khalayak sasaran berjumlah sekitar 50 peserta. Materi edukasi berisi sosialisasi tentang protocol kesehatan dalam menghadapi era new normal life pasca pandemic Covid - 19 dan pencegahan transmisi kemungkinan adanya second wave Covid- 19. Prosedur pelaksanaan pencegahan Covid 19 bagi diri sendiri dan di tempat tempat umum. ${ }^{9,10} \mathrm{Pada}$ kegiatan kegiatan latihan artinya melatih para khalayak sasaran untuk melakukan kegiatan psikomotorik dengan mendemonstrasikan cara mamakai masker yang benar, cara mencuci tangan dengan desinfectan sesuai prosedur dan protokol kesehatan. ${ }^{11,12}$ Disamping edukasi tentang protokol kesehatan, masyarakat sasaran diberikan edukasi proses pembuatan desinfectan untuk penyemprotan di tempat - tempat umum dan cara pembuatan tempat cuci tangan modern dengan metode tanpa sentuh / metode injak. Alat cuci tangan ini merupakan inovasi sebagai aplikasi IPTEK bagi masyarakat, yang dapat diadopsi dan dikembangkan oleh masyarakat sesuai dengan kebutuhan dan potensi yang tersedia di masyarakat. Untuk pendampingan dan latihan pembuatan alat cuci tangan dibantu oleh pakar las besi yang diminta sebagai konsultan pendamping. ${ }^{13,14}$

Tahap selanjutnya pemberdayaandan integrasi, merupakanpelaksanaan dari tahap edukasi dan latihan, yang didasaridari hasil forum diskusi tentang kebutuhan masyarakat Desa Temurejo yang disesuaikan dengan potensi yang tersedia di masyarakat dalam rangka menyambut adaptasi kehidupan baru di masa pendemic. Metode pengembangan pemberdayaan masyarakat melawan Covid - 19 disesuaikan dengan potensi diri masyarakat. ${ }^{15,16}$ Potensi yangtersedia di masyarakat adalah sumber daya manusia dengan kemauan yang kuat untuk menerima inovasi baru. Potensi tersebut sangat mendukung untuk terwujudnya Desa berdaya bebas Covid - 19 dengan pendekatan holistic integrative. Potensi tersebut mendapat dukungan dari perguruan tinggi yang memberikan support berupa inovasi ilmu pengetahuan dan penyediaan bahan - bahan berupa bahan desinfectan, masker dan bahan baku pembuatan alat cuci tangan modern sebagai percontohan. Pada kegiatan ini pihak perguruan tinggi sebagai pihak pemberi inovasi dan stimulasi bekerja sama dengan pakar tekhnik pembuatan tempat cuci tangan modern sebagai teknis ahli 
pengelasan. Sedangkan perguruan tinggi (team pengabdii Prodi D3 Keperawatan Blora) yang memberikan model dan tipe serta jenis alat cuci tangan dengan metode hinjakan yang berfungsi sangat efektif untuk menurunkan transmisi kuman dan virus khususnya transmisi virus corona 19. ${ }^{7,17}$

Pada tahap ke - lima atau implementasi, dilaksankan setelah semua alat dan bahan telah siap. Pada tahap ini pertama dilakukan penyerahan alat dan bahan berupa hasil karya masyarakat yaitu dua alat cuci tangan tanpa sentuh dan bahan - bahan desinfectan untuk cuci tangan dan penyemprotan tempat - tempat umum. Selanjutnya dilaksanakan kegiatan demonstrasi mencuci tangan sesuai prosedur dan penyemprotan tempat - tempat umum. Kegiatan ini dilakukan dalam tiga periode, dibawah koordinasi ketua satgas Covid - 19 . Kegiatan yang bertahap dengan harapan masyarakat dapat mempertahan perilaku hidup sehat di era pandemi. ${ }^{18}$

Kegiatan pemberdayaan masyarakat dalam mencegah transmisi Covid -19 dalam era new normal dibutuhkan suatu monitoring dan evaluaasi dengan pencatatan dan pelaporan kegiatan sebagai bahan evaluasi. Kegiatan tersebut merupakan tahap akhir dari kegiatan pengabdian kepada masyarakat melalui pengembangan desa berdaya bebas covid - 19 dengan pendekatan holistic integrative adalah monitoring dan evaluasi selanjutnya membuat dokumentasi laporan kegiatan. Setelah tahap demi tahap kegiatan dilaksanakan sesuai dengan perencanaan, didapatkan pencapaian hasil kegiatan sesuai dengan target yang diharapkan yaitu meningkatnya tingkat pengetahuan dan pemahaman masyarakat terutama Satgas Covid19, tenaga kesehatan dan kader kesehatan, tokoh masyarakat dan tokoh agama terkait pola kehidupan baru pasca pandemi Covid-19. Tercapainya peningkatan kesadaran masyarakat untuk berkonstribusi dalam pencegahan dan penanggulangan kemungkinan munculnya gelombang kedua pandemic Covid 19. ${ }^{17,19}$

Masyarakat mampu mengembangkan diri untuk menghadapi era kehidupan baru. Masyarakat mampu meningkatkan kesadaran dalam menggali potensi diri dan mengembangkan serta mewujudkanya dalam bentuk karya yang bernilai dan bermanfaat dalam menghadapi era kehidupan baru dan pencegahan munculnya gelombang kedua Covid-19. Masyarakat mampu mengembangkan upaya-upaya kreatif dan inovatif yang dapat dikembangkan menjadi usaha produktif di era pandemic maupun pasca pandemik dengan memanfaatkan potensi diri dengan metode yang komprehensif dan integrative.

Luaran dari kegiatan pengabdian diwujudkan dengan laporan pertanggungjawaban dan karya - karya berupa artikel yang dimuat dalam journal nasional dan 
modul untuk edukasi pencegahan transmisi Covid-19 dan adaptasi kehidupan baru di era pandemic. Karya inovatif yang dapat dikembangkan sesuai dengan potensi masyarakat berupa alat cuci tangan tanpa sentuh atau metode sentuh, yang dapat dikembangkan menjadi karya pemberdayaan ekonomi kreatif dalam pengembangan UMKM.

\section{Kesimpulan}

$\begin{array}{cr}\text { Secara } & \text { keseluruhan } \\ \text { pelaksanaan } & \text { kegiatan }\end{array}$

pengembangan desa berdaya bebas covid-19 di Desa Temurejo, berjalan lancar sesuai dengan perencanaan dan tujuan dan target kegiatan tercapai sesuai harapan. Beberapa faktor pendukung terlaksananya kegiatan antara lain: adanya dukungan pemerintah Desa dan Masyarakat. Pemerintah Desa membuka seluas - luasnya dukungan dari pihak luar atau perguruan tinggi pengabdi (Prodi D3 Keperawatan dan Kebidanan Blora) dan dukungan masyarakat yang diwujudkan dalam kesadaran dan kemauan masyarakat yang cukup tinggi untuk mengikuti kegiatan, menjaga hidup sehat dan mencegah infeksi virus Covid-19 serta potensi sumber daya masyarakat yang mendukung. Potensi SDM yang adekuat dalam menerima IPTEK khususnya pendampingan pembuatan alat cuci tangan dengan metode hinjak dapat dikembangkan menjadi potensi produktif yang menunjang ekonomi kreative menjadi sebuah UMKM di era new normal life. Selanjutnya diharapkan kegiatan menjaga perilaku hidup sehat berprotokol kesehatan di masa pandemi tetap dipertahankan dan menjadi kebiasaan hidup bersih dan sehat di masyarakat, dibutuhkan kegiatan yang terjadwal secara rutin.

\section{Daftar Pustaka}

[1] WHO. WHO DirectorGeneral's remarks at the media briefing on 2019-Cov, 11 February 2020. [Online]. https://www.who.int/dg/spches /detail/who-director general-sremarks-at-the-mediabriefingon-2019 ncov-on-11-february2020

[2] Gugus Tugas Percepatan Penanganan Covid-19. Data Sebaran Covid-19 Indonesia, 2020. [Online]. https://www.covid19.go.id.

[3] Erlina Burhan. Coronavirus yang Meresahkan Dunia. J Indon Med Assoc, vol.70, no.2, Februari 2020. [Online]. http://mkiojs.idionline.org/jurnal/article/ download/170/98

[4] WHO. Coronavirus diseases (COVID-19) Pandemic. 2019. [Online]. https://www.who.int/ emergencies/diseases/novelcoronavirus-2019.

[5] Kemenkes RI. Pedoman Pencegahan Dan Pengendalian Corona Virus Diseases (COVID-19). Direktorat Jenderal Pecegahan dan Pengendalian Penyakit. KMK No. HK. 01.07-MENKES4132020 tentang Pedoman Pencegahan dan Pengendalian COVID-19, 2020. 
[6] Akbar, M. W. Kampanye di Tengah New Normal Era: Mampukah Kita Berdamai dengan Pandemi?. pp.0-15, Mei 2020. [Online]. https://www.researchgate.net/p ublication/341713037_Kampa nye_di_Tengah_New_Normal _Era_Mampukah_Kita_Berda mai_dengan_Pandemi

[7] Eko, S. Pemberdayaan Masyarakat Desa. Pemberdayaan Masyarakat, vol.I, no.2, pp.87-99, 2019.

[8] Marwati, T., Aisya, I. R., \& Alifariani, A. Promosi Kesehatan Untuk Mendukung Program Sehat Dengan Pendekatan Keluarga (PIS$P K)$ Indikator Hipertensi dan $K B$ di Desa Combongan. Ed. Jurnal Pemberdayaan: Publikasi Hasil Pengabdian Kepada Masyarakat, vol.2, no.1, pp.75-82, 2018. [Online] http://garuda.ristekdikti.go.id/d ocuments/detail/899295

[9] Hutagaol, E. T., Keperawatan, F. I., Magister, P., Keperawatan, I., \& Maternitas, K. K. Efektivitas Intervensi Edukasi Pada Depresi Postpartum Tesis Diajukan Sebagai Persyaratan Untuk Memperoleh Gelar Magister Ilmu Keperawatan Kekhususan Keperawatan Maternitas Postpartum. Universitas Indonesia, 2010.

[10] World Health Organization. Materi Komunikasi Risiko COVID-19 untuk Fasilitas Pelayanan Kesehatan. World Health Organization, pp.1-11, 2020.

[11] Kemenkes RI. Pedoman Kesiapan Menghadapi COVID-19, pp.0-115, 2020.
[12] Kementrian Kesehatan RI. Pedoman COVID REV-4. Pedoman Pencegahan Dan Pengendalian Coronavirus Disease (COVID-19), 1(Revisi ke-4), pp.1-125, 2020.

[13] Angka, M., \& Tangan, K. (n.d.). Model tempat cuci tangan portable untuk menurunkan angka kuman tangan, 2020.

[14] Sukri, H. Perancangan Mesin Cuci Tangan Otomatis dan Higienis Berbasis Kamera. Rekayasa, Vol.12, no. 2, pp.163-167, 2019. https://doi.org/10.21107/rekay asa.v12i 2.5540

[15] Jacobs, a D. Holistic health care. International Journal of Orthodontics, 19(4), 15-16. 1981.

[16] MacFadyen, J. S. Holistic Nursing. Holistic Nursing Practice, 27(1), 4-5. 2013. https://doi.org/10.1097/HNP.0 b013e31827938c7

[17] Renstra, Kesehatan, J., Vol, R., \& Renstra. Kementerian Kesehatan Republik Indonesia. Kementerian Kesehatan RI. Sekretariat Jenderal. Rencana Strategis Kementerian Kesehatan Tahun Rencana Strategis Kementerian Kesehatan Tahun. vol. 7, p. 248, 2015. https://doi.org/351.077 Indr

[18] Tim Kerja Kementerian Dalam Negeri. Pedoman Umum Menghadapi Pandemi Covid19 Bagi Pemerintah Daerah: Pencegahan, Pengendalian, Diagnosis dan Manajemen. Journal of Chemical Information and Modeling, 53(9), pp.1689-1699, 2013. https://doi.org/10.1017/CBO97 81107415324.004 
[19] Dwiyanto, B. S., \& Jemadi, J. Pemberdayaan Masyarakat dan Pengembangan Kapasitas dalam Penanggulangan Kemiskinan melalui PNPM Mandiri Perkotaan. Jurnal Maksipreneur: Manajemen, Koperasi, Dan Entrepreneurship, 3(1), 36, 2013.https://doi.org/10.30588/j mp.v3i1.87 